ARTIKEL PENELITIAN

\title{
HUBUNGAN PERSENTASE DAN POLA STROMA REAKTIF DENGAN DERAJAT HISTOPATOLOGI LESI PROSTAT
}

\author{
Noza Hilbertina, Henny Mulyani \\ Bagian Patologi Anatomi, Fakultas Kedokteran Universitas Andalas \\ email : h.noza@yahoo.com
}

\begin{abstract}
Abstrak
Aktivasi dari lingkungan mikro stromal pada pejamu diperkirakan merupakan tahapan kritis dalam pertumbuhan dan progresi dari adenokarsinoma. Stroma reaktif ini sangat penting dalam merangsang invasi, progresi dan metastasis tumor. Kanker prostat adalah kanker yang tersering pada laki-laki.. Elemen pembeda pada prostat adalah fenotipe otot polos yang ada pada jaringan prostat normal sulit dibedakan dengan stroma reaktif pada pewarnaan rutin yaitu hematoksilin eosin. Dengan aplikasi pulasan Masson trichrome maka stroma normal dan stroma reaktif dapat dibedakan secara jelas. Penelitian ini bertujuan untuk mengetahui persentase dan pola distribusi stroma reaktif berdasarkan derajat histopatologi lesi prostat.

Seratus sepuluh kasus lesi prostat yang telah didiagnosis di Laboratorium Patologi FK-Unand, Padang dilakukan review ulang terhadap derajat histopatologi lesi. Selanjutnya blok parafin dari kasus yang bersangkutan dipotong ulang untuk pewarnaan Masson trichrome dan dinilai secara mikroskopik persentase dan pola stroma reaktif tersebut.

Analisis statistik menunjukkan hubungan yang kuat dan bermakna secara statistik antara persentase stroma reaktif dengan derajat histopatologi lesi prostat dengan nilai $r=0,679$ dan $p<0,05$ dan juga terdapat hubungan yang bermakna secara statistik antara pola distribusi stroma reaktif dengan derajat histopatologi lesi prostat dengan nilai $\mathrm{p}<0,05$
\end{abstract}

Kata Kunci : Derajat histopatologi, persentase stroma reaktif, pola stroma reaktif

\section{Abstract}

Activation of the host stromal microenvironment is predicted to be a critical step in adenocarcinoma growth and progression. Reactive stroma in cancer would be predicted to enhance tumor progression, stimulating invasion and metastasis. Prostat cancer is the most cancer in men. Prostat cancer reactive stroma is composed of a myofibroblast/fibroblast mix. A simple trichrome stain makes the process of distinguishing normal stroma and reactive stroma more obvious. We examined the association of percentage and pattern of reactive stroma to histopatologic grading from the prostate lesions.

A hundred and ten of prostate lesion were obtain from the Pathological Anatomic Laboratorium, Medical Faculty of Andalas University in Padang. The hematoxilin 
eosin slides were reviewed by two viewer for histopathologic grading and than whole mount thin section were stained with Masson trichrome. To evaluate the reactive stromal interpretation classified in to percentage $(+,++,+++)$ and pattern of reactive stroma (regular and irregular).

There were significant association between percentage of reactive stroma with histopathologic grading statistically $(\mathrm{p}<0,05$ and $\mathrm{r}=0,679)$ and significant association between pattern of reactive stroma with histopathologic grading statistically $(\mathrm{p}<0,05)$.

Key word : histopathologic grading, percentage, pattern 


\section{Pendahuluan}

Aktivasi dari lingkungan mikro stromal pada pejamu diperkirakan merupakan tahapan kritis dalam pertumbuhan dan progresi dari adenokarsinoma. Beberapa kanker pada manusia menunjukkan adanya induksi reaksi stromal atau desmoplasia sebagai komponen dari progresi karsinoma. ${ }^{(1)}$

Reaksi stromal pada kanker menunjukkan respon yang mirip dengan respon penyembuhan luka secara umum. Sel stromal pada penyembuhan luka menunjukkan peningkatan produksi komponen maktriks ekstraseluler (MES), faktor-faktor pertumbuhan, dan enzim-enzim pengaturan matriks sehingga tercipta lingkungan mikro yang menunjang pertumbuhan. Stroma reaktif pada kanker diperkirakan berperan dalam meningkatkan progresi tumor melalui perangsangan angiogenesis, peningkatan invasi, proliferasi dan ketahanan sel tumor. Pada dua penelitian terakhir, terlihat bahwa sel stromal prostat merangsang perkembangan tumorigenesis prostat pada tikus model xenograft.$^{(1)}$

Stroma reaktif adalah campuran dari fibroblast, myofibroblast, sel endotel dan sel-sel imunitas. Meskipun kesemua sel tersebut dapat mempengaruhi tumorigenesis, namun myofibroblast merupakan sel yang paling menarik perhatian. Myofibroblast adalah sel stromal yang diaktifkan dan terutama ditemukan pada tempat penyembuhan jaringan yang sakit. Pada penyembuhan luka, myofibroblast berasal dari fibroblast jaringan granulasi. Pada kanker, diketahui bahwa sel karsinoma memiliki kapasitas untuk menginduksi fibroblast normal menjadi fenotipe myofibroblast reaktif. ${ }^{(1)}$

Pada stroma reaktif, myofibroblast mensintesis komponen MES seperti kolagen tipe I, kolagen tipe III, isoform fibronectin, tenascin, dan ver- sican. Selain itu, myofibroblast mengekspresikan protease-protease seperti urokinase plasminogen activator (UPA), FAP dan matrix metalloproteinase (MMPs). Produksi dari komponen-komponen ini mengakibatkan pengaturan MES yang dapat merangsang pertumbuhan dan migrasi sel kanker. Lebih lanjut juga diketahui bahwa myofibroblast mensekresikan faktor-faktor pertumbuhan yang merangsang angiogenesis. Dengan demikian myofibroblast merupakan sel kunci yang terlibat dalam pembentukan lingkungan stroma reaktif yang merangsang pertumbuhan tumor. ${ }^{(1)}$

Peranan dari sel-sel radang dan sel endotel dalam proteksi dan angiogenesis tumor telah diterangkan pada berbagai penelitian namun sedikit sekali diketahui tentang peranan myofibroblast dalam karsinogenesis prostat. Bagaimana sel-sel tersusun di dalam jaringan disebut dengan distribusi sel. Terdapat pertanyaan apakah distribusi sel stromal didalam karsinogenesis tersebut bersifat acak ataukah distribusi tersebut mempengaruhi perangai tumor yang invasif serta prognosis tumor tersebut. Masih sedikit penelitian yang dilakukan untuk menilai distribusi sel elemen stromal dan kepentingannya dalam proses bertingkat dari karsinogenesis kanker prostat. Beberapa penelitian terdahulu menduga bahwa terdapat peranan dari keberadaan dan distribusi myofibroblast dalam memfasilitasi progresi tumor. Namun, beberapa penelitian lainnya hanya menjelaskan tentang distribusi sel myofibroblast dan tidak meneliti hubungannya dengan karakteristik tumor invasif. ${ }^{(2)}$

Tuxhorn et al., 2002 pada penelitiannya menemukan pada karsinoma prostat diferensiasi sedang adanya predominan warna biru dengan hanya sedikit warna merah pada stroma yang 
telah dipulas dengan Masson trichrome. Pola warna biru ini konsisten berhubungan dengan area kanker dan diduga bahwa lingkungan mikro stroma tumor kehilangan fenotipe asalnya otot polos disertai peningkatan kolagen.

Ayala et al., 2003 pada penelitiannya menemukan pasien kan-ker prostat dengan persentase stroma reaktif 5- $49 \%$ memiliki angka ketaha-nan bebas rekuren $70-80 \%$, sedangkan pasien dengan persentase stroma reaktif $\geq 50 \%$ memiliki angka ketahanan bebas rekuren antara 50-60\%. ${ }^{(3)}$

Stroma prostat normal adalah fenotipe otot polos sehingga respon desmoplastik stroma pada prostat kurang jelas pada sediaan histopatologi dengan pulasan hematoksilin-eosin. Pemakaian pulasan Masson trichrome dapat membedakan dengan jelas antara stroma normal dan stroma reaktif.

Dengan demikian perlu kiranya dilakukan review persentase dan pola distribusi dari myofibroblast sebagai komponen utama dari stroma reaktif serta hubungannya dengan derajat histopatologi lesi prostat. Penelitian ini bertujuan untuk mengetahui hubungan persentase dan pola distribusi stroma reaktif dengan derajat histopatologi lesi prostat.

\section{Bahan dan Metode Penelitian}

Penelitian ini adalah penelitian observasional dengan pendekatan cross sectional. Populasi adalah blok paraffin dari kasus hiperplasia prostat, PIN derajat tinggi (PIN HG) dan karsinoma prostat yang telah didiagnosis pada Laboratorium Patologi Anatomi FKUNAND. Berdasarkan rumus didapat besar sampel sebanyak 110 kasus yang diambil dari sediaan periode April 2010 - Maret 2011.

Data-data pasien didapat dari lembar permintaan pemeriksaan. Sediaan histopatologi rutin dengan pewarnaan hematoksilin-eosin dilakukan review ulang untuk klasifikasi derajat histopatologi. Sedangkan blok paraffin dari sediaan yang bersangkutan dipotong ulang untuk pemulasan Masson Trichrome.

Lesi histopatologi dikelompokkan atas hiperplasia prostat, PIN derajat tinggi (PIN HG) dan karsinoma prostat sesuai dengan kriteria mikroskopik yang telah ditetapkan oleh WHO.

Sedangkan sediaan pulasan Masson Trichrome, dilakukan penilaian terhadap pola dan persentase stroma reaktifnya. Kriteria penilaiannya adalah sebagai berikut :

Persentase stroma reaktif dinilai secara semi kuantitatif yaitu : (Kellermann et al. 2007). ${ }^{(2)}$

Positif satu (+) : jika 0-15\% stroma disekitar kelenjar lesi prostate terpulas biru dengan Masson trichrome.

Positif dua (++) : jika > 15\% - <50\% stroma disekitar kelenjar lesi prostate terpulas biru dengan Masson trichrome. Positif tiga $(+++)$ : jika $>50 \%$ stroma disekitar kelenjar lesi prostate terpulas biru dengan Masson trichrome. (Skala ordinal).

Penilaian dilakukan terhadap stroma disekitar lesi kelenjar prostat, pada perbesaran 200x, pada 3 lapangan pandang. Jika persentase stroma reaktif $(++)$ atau $(+++)$ maka penilaian dilanjutkan dengan penilaian terhadap pola distribusi stroma tersebut.

Pola distribusi stroma reaktif dikelompokkan atas tiga macam yaitu $:^{(2)}$

Fokal : myofibroblast memiliki susunan fokal atau tidak ada susunan khusus pada area yang berbeda dari jaringan penyambung.

Jaring : myofibroblast tersusun dalam baris multipel dengan serat saling silang 
dari perpanjangan sitoplasma yang mencakup pola fokal dan jaring. membentuk jaring (network) dalam Penilaian pola distribusi stroma reaktif stroma dari jaringan penyambung. hanya dilakukan pada kelompok persentase $>15 \%$. Penyederhanaan ini Spindel : myofibroblast tersusun dalam dilakukan untuk menghindari subjektisatu hingga tiga baris dalam susunan fitas diantara pengamat. Penilaian yang teratur di pinggir dari sel neo- mikroskopik dilakukan dengan mengplastik atau dalam jaringan penyambung dengan batas sel yang jelas disekitar myofibroblast. Skala nominal. Penilaian dilakukan pada stroma disekitar lesi kelenjar prostat, perbesaran 200x, pada 3 lapangan pandang.

Namun pada penelitian ini kami gunakan mikroskop cahaya binocular.

\section{Hasil}

Dari 110 sampel tersebut seluruhnya berusia diatas 50 tahun dengan kelompok umur 61-70 tahun sebagai kelompok umur terbanyak. memakai dua macam pola distribusi Karakteristik dari sampel penelitian saja yaitu pola teratur yang mencakup dapat dilihat pada tabel 1 berikut. pola spindel dan pola tidak teratur yang

Tabel 1. Distribusi Karakteristik Sampel Penelitian

\begin{tabular}{lcc}
\hline Karakteristik & Frekuensi (f) & Persentase (\%) \\
\hline Umur & 21 & 19,1 \\
$51-60$ & 51 & 46,4 \\
$61-70$ & 33 & 30,0 \\
$71-80$ & 5 & 4,5 \\
$81-90$ & & \\
Lesi Prostat & 58 & 52,7 \\
Hiperplasia & 33 & 30,0 \\
PIN derajat tinggi (PIN HG) & 19 & 17,3 \\
Karsinoma & & 64,4 \\
Stroma reaktif & & 38,6 \\
Positif 1 (+) & 51 & 15,5 \\
Positif 2 (++) & 42 & \\
Positif 3 (+++) & 17 & \\
Pola distribusi stroma reaktif & & \\
Teratur & & \\
Tidak teratur & & \\
\hline & & \\
\hline
\end{tabular}


Tabel 2. Persentase stroma reaktif berdasarkan derajat histopatologi lesi prostate

\begin{tabular}{lrrrr}
\hline Lesi Prostat & \multicolumn{3}{c}{ Stroma reaktif } & Jumlah \\
\cline { 2 - 4 } & \multicolumn{1}{c}{$(+)$} & $(++)$ & $(+++)$ & \\
\hline Hiperplasia & $48(82,8)$ & $7(12,1)$ & $3(5,2)$ & $58(100)$ \\
PIN HG & $3(9,1)$ & $24(72,7)$ & $6(18,2)$ & $33(100)$ \\
Karsinoma & $0(0)$ & $11(57,9)$ & $8(42,1)$ & $19(100)$ \\
\hline Jumlah & $51(46,4)$ & $42(38,2)$ & $17(15,5)$ & $p<0,05$
\end{tabular}

Pada tabel 2 dapat dilihat sebagian reaktif $(+++)$. Analisis statistik dengan besar lesi hiperplasia prostat $(82,8 \%)$ Chi-square tests menyimpulkan bahwa hanya memiliki stroma reaktif dengan terdapat hubungan yang bermakna persentase 0-15\% saja. Untuk kelompok secara statistik dengan nilai $\mathrm{p}<0,05$. ini tidak dilanjutkan dengan penilaian Uji Kendall's didapatkan nilai $r=0,678$ pola stroma reaktif tersebut. Sedangkan dengan $\mathrm{p}<0,05$. Dengan demikian lesi PIN HG, sebagian besar kasus semakin tinggi derajat histopatologi $(72,7 \%)$ memiliki stroma reaktif $(++)$. semakin tinggi pula persentase stroma Sebagian karsinoma prostat $(57,9 \%)$ reaktif dan hubungan ini kuat serta juga memiliki stroma reaktif (++), dan bermakna secara statistik. sisanya yaitu $42,1 \%$ memiliki stroma

Tabel 3. Pola stroma reaktif berdasarkan derajat histopatologi lesi prostate

\begin{tabular}{|c|c|c|c|}
\hline \multirow[t]{2}{*}{ Lesi Prostat } & \multicolumn{2}{|c|}{ Pola distribusi } & \multirow[t]{2}{*}{ Jumlah } \\
\hline & Teratur & Tidak teratur & \\
\hline Hiperplasia & $7(70,0)$ & $3(30,0)$ & $10(100)$ \\
\hline PIN HG & $13(43,3)$ & $17(56,7)$ & $30(100)$ \\
\hline Karsinoma & $1(5,3)$ & $18(94,7)$ & $19(100)$ \\
\hline Jumlah & $21(35,6)$ & $38(64,4)$ & $59(100)$ \\
\hline
\end{tabular}

Tabel 3 memperlihatkan sebagian besar lesi hiperplasia prostat yang memiliki stroma reaktif $>15 \%$, menunjukkan pola distribusi yang teratur $(70,0 \%)$, bermakna secara statistik dengan nilai $\mathrm{p}$ sedangkan lesi PIN HG sebagian besar < 0,05.

memperlihatkan pola distribusi stroma Gambaran persentase dan pola reaktif yang tidak teratur $(56,7 \%)$. distribusi dari stroma reaktif dari Begitu pula dengan lesi karsinoma pulasan Masson trichrome dapat dilihat prostat yang hampir seluruhnya berturut-turut pada gambar berikut. memperlihatkan pola distribusi yang tidak teratur $(94,7 \%)$. Analisis statistik dengan Chi-square tests menyimpulkan bahwa terdapat hubungan yang rerturut-turut pada gambar berikut. 


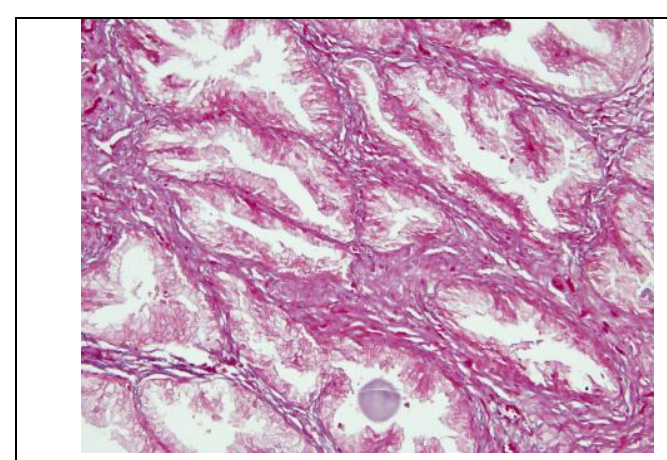

Gambar 1 Hiperplasia prostate, stroma reaktif (+). (Masson trichrome, perbesaran 10x10)

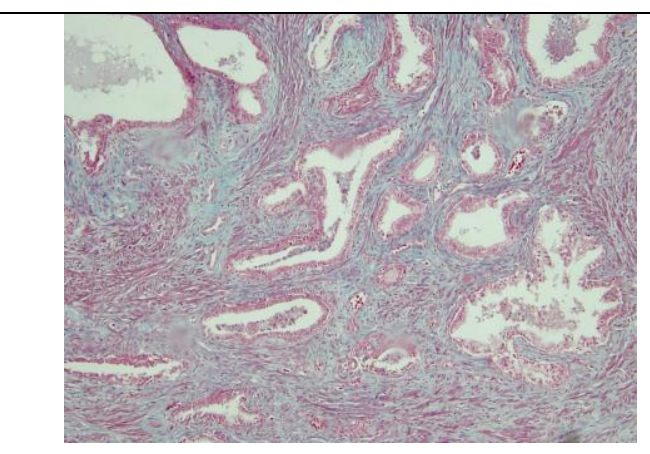

Gambar 3. PIN HG, stroma reaktif $(+++)$, pola teratur. (Masson trichrome, perbesaran 20x10)

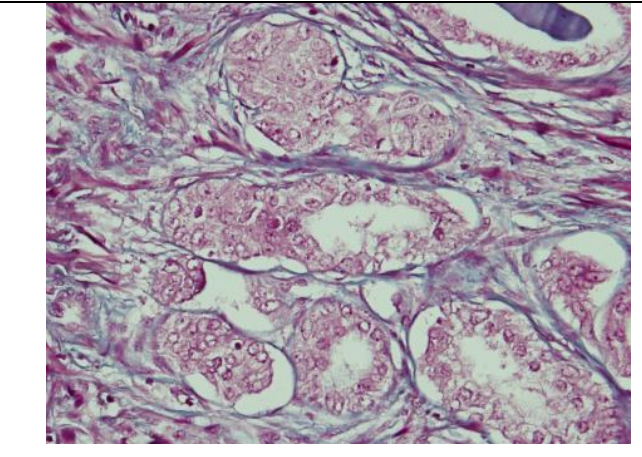

Gambar 2. PIN HG, stroma reaktif $(++)$, pola tidak teratur. (Masson trichrome, perbesaran 20x10)

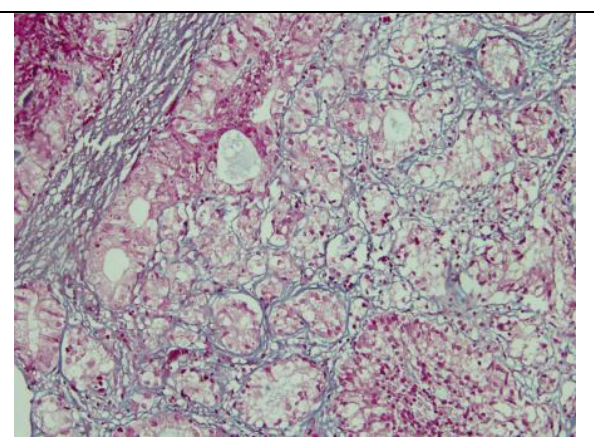

Gambar 4. Karsinoma, stroma reaktif $(+++)$, pola tidak teratur. (Masson trichrome, perbesaran 20x10)

frekuensi masing-masingnya $9 \%$ dan

\section{Diskusi}

Seluruh sampel pada penelitian ini berusia diatas 50 tahun. Secara teoritis dinyatakan bahwa hiperplasia prostat ditemukan dalam jumlah yang bermakna pada usia 40 tahun dan makin meningkat seiring pertambahan usia dan mencapai $90 \%$ pada dekade delapan. ${ }^{(4)}$ Pada penelitian ini lesi hiperplasia prostat ditemukan pada usia diatas 50 tahun. Dari laporan penelitian yang telah dilakukan diketahui bahwa PIN HG dapat terdeteksi secara mikroskopik pada lelaki muda dan prevalensi nya meningkat seiring dengan pertambahan usia. Neoplasia intraepitelial prostat ini menunjukkan asosiasi yang kuat dengan kanker prostat dimana lesi ini sering ditemukan koinsiden pada kelenjar yang sama. ${ }^{(5)}$

Dari satu penelitian pada lelaki muda, menunjukkan bahwa PIN pertama kali terlihat pada usia 20 tahunan dan 30 tahunan dengan
$22 \%$. Keadaan ini mendahului onset karsinoma lebih dari 10 tahun. Sebagian besar fokus PIN pada lelaki muda adalah berupa PIN low grade (PIN LG). ${ }^{(6)}$

Tidak berbeda dengan lesi PIN HG maka karsinoma prostat juga memiliki peningkatan risiko sejalan dengan peningkatan usia. Karsinoma prostat merupakan penyakit yang predominan pada laki-laki tua dengan puncak insiden pada usia 65 dan 75 tahun. Kanker prostat yang laten lebih sering dibandingkan dengan yang menampakkan gejala klinis dengan frekuensi secara keseluruhan lebih dari $50 \%$ pada laki-laki diatas usia 80 tahun. ${ }^{(4)}$

Proporsi lesi prostat pada penelitian ini memperlihatkan bahwa hiperplasia merupakan lesi terbanyak $(52,7 \%)$ diikuti oleh PIN HG $(30,0 \%)$ dan karsinoma (17,3\%). Dalam literatur 
dinyatakan bahwa sebagian besar lesi hiperplastik berasal dari zona transisional dalam dan zona sentral dari prostat. Adanya lesi pada zona ini akan lebih cepat menimbulkan gejala obstruksi uretra sehingga pasien lebih cepat memeriksakan diri. Sedangkan lesi karsinoma sebagian besar (70-80\%) berasal dari zona perifer yang relatif lebih lambat menimbulkan gejala obstruksi. $^{(4)}$

Proporsi ini bisa saja berbeda dengan kejadian sebenarnya karena yang dimasukkan dalam penelitian ini tentunya pasien dengan gejala klinis yang datang memeriksakan diri ke layanan kesehatan dan bersedia untuk dilakukan tindakan bedah. Disamping itu adanya karsinoma yang laten tanpa gejala klinis sampai penderitanya meninggal dunia juga dapat terjadi.

Kompartemen stromal dari jaringan diketahui berperan penting dalam pertumbuhan tumor termasuk progresi dari kanker prostat. Stroma bukan hanya sebagai penyokong neoplasma epitelial yang diam, namun juga berperan secara aktif dan dinamis dalam tumorigenesis dan progresi kanker prostat. ${ }^{(7)}$

Dari penelitian Chung, seperti yang ditulis oleh Veltri et al., 2004, ${ }^{(7)}$ diajukan bahwa fibroblast yang tumorigenik yang diinduksi oleh proliferasi epitel, kemudian diorganisasi ke dalam bentuk adenokarsinoma melalui interaksi sel dengan sel. Fibroblast yang tumorigenik ini juga menunjukkan efek penguatan pada sel karsinoma prostat pada manusia dan tikus.

Hayward et al, mengajukan hipotesis bahwa terjadi kerusakan bertahap dalam homeostatis interaksi antara sel epitel dan sel otot polos yang berakibat hilangnya pensinyalan morfogenik dan homeostatis diantara sel karsinoma prostat dengan sel otot polos lokal. Dengan demikian sel otot polos akan teramati berkurang secara progresif disekitar adenokarsinoma prostat selama progresi kanker dari derajat rendah menjadi derajat yang tinggi. Berdasarkan hipotesis stroma reaktif ini maka karakteristik myofibroblast pada stroma reaktif dapat diidentifikasi secara imunohistokimia dengan antibody smooth muscle $\alpha$-actin sebagai penanda yang umum dipakai untuk stroma reaktif pada kanker prostat. ${ }^{(7)}$

Namun dengan teknik yang lebih murah stroma reaktif ini juga dapat dinilai dengan pulasan histokimia yaitu Masson trichrome. Dengan pulasan ini struktur stroma yang kolagenous akan terwarnai biru sedangkan sel otot polos akan terwarnai merah.

Penelitian ini bertujuan untuk menilai hubungan persentase stroma rekatif serta pola distribusinya dengan derajat histopatologi lesi prostat. Sebagian besar lesi hiperplasia $(82,8 \%)$ memiliki persentase stroma reaktif antara $0-15 \%$, sedangkan lesi PIN HG sebagian besar $(72,7 \%)$ memiliki stroma reaktif $>15 \%$ - $<50 \%$. Berbeda dengan karsinoma yang semuanya memiliki stroma reaktif $>15 \%$. Lima puluh tujuh koma sembilan persen karsinoma prostat memiliki stroma reaktif $>15 \%$ - $<50 \%$, dan sisanya $42,1 \%$ menunjukkan stroma reaktif $>50 \%$. Tidak satupun karsinoma prostat dengan stroma reaktif dibawah $15 \%$. Analisis statistik dengan Chi-square tests untuk mengetahui hubungan antara persentase stroma reaktif dengan derajat histopatologi lesi prostat menyimpulkan bahwa terdapat hubungan yang bermakna secara statistik dengan nilai $p<$ 0,05. Dari uji Kendall's didapatkan hubungan yang sedang dengan $r=$ 0,678, dan hubungan ini bermakna secara statistik dengan $p<0,05$. Hal ini 
berarti semakin tinggi derajat histopatologi lesi, semakin tinggi pula persentase stroma reaktif.

Peningkatan persentase stromal yang terwarnai biru disekitar kelenjar dari lesi prostat dengan pulasan Masson trichrome ini menyiratkan hilangnya tipikal sel otot polos disertai dengan peningkatan kolagen pada stroma prostat.

Stroma reaktif diduga dapat mempromosi progresi kanker terutama pada stadium awal dari tumorigenesis. Tuxhorn, Ayala, Smith, 2002 ${ }^{(1)}$ melaporkan bahwa terdapat peningkatan fibroblast dan myofibroblast pada stroma periacinar dari fokus PIN. Selain itu terlihat adanya lapisan fibroblast yang menebal pada beberapa area. Data ini menimbulkan dugaan adanya aktifasi lokal dari fibroblast periacinar sebagai respon terhadap PIN.

Tuxhorn, Ayala, Smith, 2002(1) juga mengamati warna biru yang intens dengan pulasan Masson trichrome pada stroma karsinoma prostat. Warna biru ini terlihat disekitar kelenjar lesi. Pengamatan ini menunjukkan bahwa matriks ekstraselular dari PIN mungkin telah mengalami remodeling dan aktifasi sel stromal serta remodeling matriks ekstraselular telah diinduksi pada stadium PIN. Lebih lanjut, peningkatan fibroblast/myofibroblast periacinar, dan peningkatan sintesis kolagen sepertinya memisahkan sel PIN dari sel otot polos dari prostat normal.

Penelitian yang berbeda dilakukan oleh Ayala et al., 2003. ${ }^{(3)}$ Penilaian persentase stroma reaktif dilakukan hanya pada lesi karsinoma prostat yang kemudian dihubungkan dengan angka ketahanan bebas rekuren pada pasien tersebut. Dari 545 spesimen tumor pasien yang diperiksa maka $64,1 \%$ nya menunjukkan stroma reaktif $>15 \%$. Dari data follow up pasien tersebut terlihat bahwa pasien dengan stroma reaktif $5-50 \%$ memiliki angka ketahanan bebas rekuren antara 70$80 \%$, sedangkan pasien dengan stroma reaktif $>50 \%$ atau $0-5 \%$ memiliki angka ketahanan bebas rekuren yang lebih rendah yaitu 50 dan 60\%. Namun terdapat perbedaan teknik penilaian stroma reaktif antara peneliti dengan Ayala et al, 2003. ${ }^{(3)}$ Ayala menghitung persentase stroma reaktif tersebut berdasarkan ratio stroma dengan epitel, sedangkan pada penelitian ini kami menghitung persentase stroma yang terwarnai biru (kolagenous) dengan stroma yang masih berwarna merah (otot polos) yang terdapat disekitar kelenjar lesi.

Meskipun sebagian besar lesi hiperplasia mengadung stroma reaktif hanya $0-15 \%$ namun ada juga lesi ini $(5,2 \%)$ dan $18,2 \%$ lesi PIN HG yang menunjukkan stroma reaktif $>50 \%$. Temuan ini memerlukan penelitian lebih lanjut untuk menilai kemaknaannya. Apakah lesi jinak dengan persentase stroma reaktif yang tinggi akan mengalami progresi yang cepat menjadi lesi preneoplastik atau bahkan lesi neoplastik ganas. Apakah lesi preneoplastik dengan persentase stroma reaktif yang berbeda juga akan berpengaruh terhadap kecepatan progresi lesi menjadi lesi neolastik ganas. Dari penelusuran peneliti, belum ada yang melaporkan tentang kemaknaan perbedaan stroma reaktif lesi jinak dan preneoplastik terhadap progresi lesi tersebut.

Pada penelitian ini peneliti juga menilai pola dari stroma reaktif. Penilaian hanya dilakukan pada stroma reaktif $>15 \%$. Hal ini didasarkan kepada jumlah stroma yang cukup adekuat untuk penilaian polanya. Pada awalnya kami mengelompokkan pola tersebut atas 3 yaitu fokal, jaring dan spindel. Hal ini berdasarkan penelitian yang dilakukan oleh Seifi et al.,2010. ${ }^{(2)}$ Seifi 
et al., 2010 menilai stroma reaktif pada berbagai derajat lesi skuamosa di daerah mulut. Namun pada akhirnya kami hanya mengelompokkan pola distribusi tersebut kedalam 2 kelompok yang lebih sederhana yaitu pola teratur yang mencakup pola spindel dan pola yang tidak teratur yang mencakup pola fokal dan jaring.

Sebagian besar stroma reaktif pada hiperplasia $(70 \%)$ menunjukkan pola teratur. Sebaliknya dengan lesi PIN HG dan karsinoma yang sebagian besar stroma reaktifnya menunjukkan pola tidak teratur $(56,7 \%$ dan $94,7 \%)$. Analisis statistik dengan Chi-square tests untuk menilai hubungan antara pola distribusi stroma reaktif dengan derajat histopatologi lesi menyimpulkan bahwa terdapat hubungan yang bermakna secara statistik dengan nilai $\mathrm{p}$ $<0,05$.

Hasil ini sejalan dengan temuan Seifi et al., 2010 yang menemukan bahwa terdapat hubungan yang bermakna secara statistik antara distribusi selular stroma reaktif dengan derajat lesi yaitu lesi pre kanker dan kanker.

Sepertinya makin tinggi persentase stroma reaktif maka makin invasif perangai tumor. Hal ini berdasarkan fakta bahwa matriks metalloproteinase yang disekresikan oleh myofibroblast sebagai komponen stroma reaktif berperan dalam invasifitas tumor. Matriks metalloproteinase berperan dalam penghancuran matriks ekstraseluler, pembentukan tumor, migrasi, invasi, metastasis, angiogenesis dan induksi klon apoptotik (Lynch et al., 2002 dikutip dari Seifi et al., 2010).(2) Semakin banyak stroma reaktif yang tersusun tidak teratur (jaring) maka akan memperlihatkan perangai yang lebih invasif dibandingkan dengan yang tersusun teratur (spindel). Namun sampai saat ini sedikit laporan penelitian tentang pola distribusi ini sehingga perlu penelitian lebih lanjut dengan jumlah sampel yang lebih banyak.

Shimaki et al.,2006 melaporkan peranan dari distribusi dan susunan stroma reaktif (myofibroblast) pada karsinoma buli-buli dan perangai tumor invasif. Susunan fascicular dan reticular terlihat masing-masing pada karsinoma buli-buli invasif dan non invasif. Mereka menyimpulkan bahwa distribusi myofibroblast dapat memberikan informasi karakteristik invasi karsinoma. ${ }^{(2)}$

Penelitian ini masih memerlukan penelitian lanjutan untuk menilai kemaknaan stroma reaktif pada lesi hiperplasia dan PIN HG terhadap progresi lesi dan kemungkinan rekurensi pada lesi karsinoma.

\section{Kesimpulan}

1. Terdapat hubungan yang bermakna secara statistik antara persentase stroma reaktif dengan derajat histopatologi lesi prostat dengan nilai $\mathrm{r}=0,679$ dan $\mathrm{p}<$ 0,05 .

2. Terdapat hubungan yang bermakna secara statistik antara pola distribusi stroma reaktif dengan derajat histopatologi lesi prostat dengan nilai $\mathrm{p}<0,05$.

\section{Saran}

Perlu penelitian lebih lanjut untuk menilai kemaknaan stroma reaktif pada lesi hyperplasia dan PIN HG terhadap progresi lesi dan kemungkinan rekurensi pada lesi karsinoma.

\section{KEPUSTAKAAN}

1. Tuxhorn JA, Ayala GE, Smith MJ Et Al., 2002, Reactive Stroma In Human Prostat Cancer: Induction Of Myofibroblast Phenotype And Extracellular Matrix 
Remodeling, Clin Cancer Res 8, 2912-23.

2. Seifi S Et Al., 2010, Myofibroblast Stromal Presence And Distribution In Squamous Epithelial Carcinoma, Oral Dysplasia And Hyperkeratosis, Asian Pacific J Cancer Prev, 11: 359-64.

3. Ayala G Et Al., 2003, Reactive Stroma As Predictor Of Biochemical-Free Recurrence In Prostate Cancer, Clinical Cancer Research, 9.

4. Burns DK, 2003, The Male Genital System in Robbins Basic Pathology, $7^{\text {th }}$ ed, Saunders, Philadelphia, 664-69.

5. Sakr WA, Montironi R, Epstein JI, Rubin MA, 2004, Prostatic intraepithelial neoplasia in WHO Classification of Tumour;
Pathology and genetics of tumours of the urinary system and male genital organs, IARC Press, Lyon.

6. Bostwick DG And Qian J, 2004, High-Grade Prostatic Intraepithel Neoplasia, Modern Pathology, 17: 360-79.

7. Veltri RW, Park J, Miller MC et al., 2004, Stromal-epithelial measurements of prostate cancer in native Japanese and JapaneseAmerican men ; Prostate Cancer and Prostatic Diesase 7, 232-7.

8. Sastroasmoro S, Ismael S, 2008, Dasar-dasar Metodologi Penelitian Klinis. Sagung Seto, Jakarta.

9. Sabri L, Hastono SP, 2006. Statistik Kesehatan. Edisi revisi. PT. Raja Grafindo Persada, Jakarta. 